Research Article

\title{
Effect of Adding Chelating Agents on the Absorption of Zinc from Polluted Soil Sludge Textile Industrial Waste by Sunflower Plant (Helianthus annuus L.)
}

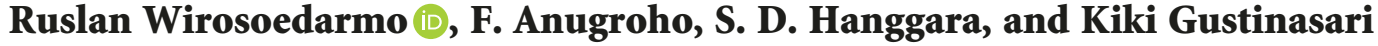 \\ Department of Agricultural Engineering, Faculty of Agricultural Technology, Brawijaya University, Jalan Veteran, \\ Malang 65145, Indonesia
}

Correspondence should be addressed to Ruslan Wirosoedarmo; ruslanwr@ub.ac.id

Received 5 January 2018; Revised 20 March 2018; Accepted 8 April 2018; Published 22 May 2018

Academic Editor: Teodoro M. Miano

Copyright (c) 2018 Ruslan Wirosoedarmo et al. This is an open access article distributed under the Creative Commons Attribution License, which permits unrestricted use, distribution, and reproduction in any medium, provided the original work is properly cited.

\begin{abstract}
Textile industry caused the increase of the heavy metal $\mathrm{Zn}$ in soil in the form of sludge. Waste treatment by the phytoremediation method is one of the alternatives of environmental refinement with low cost and high effectiveness. This study used sunflower plants (Helianthus annuus L.) as a phytoremediator. The chelating agent EDTA was added in some treatment to increase the heavy metal absorption. The addition of $1.5 \mathrm{~kg}$ sludge on growth media inhibits the sunflower growth. T0K0 treatment has the most efficient result with a total $\mathrm{Zn}$ absorption of $101.74 \mathrm{mg} / \mathrm{kg}$. T0K0 treatment was able to reduce $\mathrm{Zn}$ up to $96 \%$. In $100 \%$ soil treatment, the EDTA additions decreased the ability of sunflower plants to absorb Zn metal in the phytoremediation process. However, in the $40 \%$ sludge treatment, the addition of EDTA did not affect the ability of sunflower plants to absorb the $\mathrm{Zn}$ metal in the phytoremediation process.
\end{abstract}

\section{Introduction}

Wastes are the major source of soil pollution and originate from mining, chemical, and metal-processing industries, textile industry, leather equality industry, and other allied industries $[1,2]$. The development of the textile industry creates some negative impacts on the environment, one of which is the increase of the heavy metal $\mathrm{Zn}$ in the soil in the form of sludge [3-5]. The soil serves for providing nutrients, as a rooting medium, providing water, as a reservoir of water, and providing air for root respiration, as a place of cultivation of plants $[4,6,7]$.

Generally, zinc is an essential element which belongs to Group-II of the periodic table. It acts as a plant nutrient, but at higher concentrations, it is toxic [8]. Zinc is also a constituent of metalloenzyme or a cofactor for several enzymes such as anhydrases, dehydrogenases, oxidases, and peroxidases and plays an important role in regulating the nitrogen metabolism, cell multiplication, photosynthesis, and auxin synthesis in plants [9-12]. The function of zinc is to help a plant to produce chlorophyll. When the soil is deficient in zinc, leaves get discolored and plant growth is stunted [12-14]. Zinc deficiency causes leaf discoloration called chlorosis, a condition that causes tissue of the veins to turn yellow. Zinc toxicity also causes chlorosis in the younger leaves, which can extend to older leaves after prolonged exposure to high soil $\mathrm{Zn}$ levels $[8,15]$. Zinc in excess reduces the germination, chlorophyll, carotenoid, sugar, amino acid, and growth of cluster beans (Cyamopsis tetragonoloba) [1].

The toxicity of heavy metals is apparent in reducing growth and development of plants and seriously harms the health of animals and humans [2]. Increasing the concentration of the heavy metal $\mathrm{Zn}$ in the environment can cause serious effects on all life forms. For plants, heavy metal $\mathrm{Zn}$ pollution can cause shortening of the roots, leaf loss, chlorosis, and nutritional deficiencies. However, in pea (Pisum sativum), it reduces chlorophyll, photosynthesis, and plant growth $[16,17]$. In rye grass (Lolium perenne), it reduces the growth, nutrient content, and photosynthetic energy conversion [18]. The acquired knowledge is to be used in planning 
of biomass processing systems and, in parallel, in phytoremediation of polluted soils, using cultivation of energy plants as a main concept $[19,20]$. One technology that can be used to remediate the contaminated soil of heavy metals is phytoremediation [21, 22]. Phytoremediation is the use of plants for removal, stabilization, or destruction of pollutants in both organic and inorganic compounds $[8,15]$.

The phytoremediation method has several advantages such as the method used is simple, efficient, cost-effective, and environmentally friendly [15]. In the phytoremediation process, sunflower plants (Helianthus annuus L.) are used as phytoremediators because these plants are hyperaccumulators and are fast growing plants with high biomass production [23, 24]. In addition to plant species, the phytoremediation process is also influenced by the presence of the chelating agent [25].

The purpose of this research was to know the effect of adding a chelating agent to the absorption of sludge containing contaminated heavy metal by using sunflower plants (Helianthus annuus L.)

\section{Methodology}

2.1. Study Area. This research was conducted in Greenhouse, Integrated Laboratory, University of Brawijaya. This location is on the line $112^{\circ} 36^{\prime} 43^{\prime \prime}$ East longitude and $7^{\circ} 54^{\prime} 58^{\prime \prime}$ South latitude. This research was conducted in March 2017 until July 2017. Sludge of the textile industry was taken from PT. Behaestex, Pandaan, Pasuruan, Indonesia. Testing of the heavy metal content of $\mathrm{Zn}$ on soil and sunflower plant was tested using spectrophotometry at Chemical Laboratory, Faculty of Mathematics and Natural Sciences, University of Brawijaya, Malang, East Java, Indonesia.

2.2. Instruments. Some tools used in this research include pots as a place of planting media, sacks carrying planting medium, a jerigen container for sludge, shovels to plant crops, an analytical scale measuring plant mass, a soil tester to measure $\mathrm{pH}$ and temperature, a measuring cylinder to measure sludge volume, an oven for drying samples, gloves and masks as personal protective equipment, sample bottles as sample containers, stationery for pot information, a camera as a documentation tool, atomic absorption spectrophotometry (SSA) as a tool for testing heavy metal content of $\mathrm{Zn}$, tubes reaction as a sample mixing container, a filter paper to filter the sample, an Erlenmeyer flask as a sample container, and a blender to smoothen the sample.

2.3. Materials. Materials used in this research include soil as planting medium, sludge as planting medium and treatment, sunflower plant as planting medium and treatment, compost as a provider of organic material for the plant and is useful to improve the soil structure, EDTA as the treatment material, water to watering plant, and $\mathrm{ZnCl}_{2}$ to add the $\mathrm{Zn}$ content in the treatment.

\subsection{Research Stages}

2.4.1. Planting Medium. Prepare the pot as a container of planting media as many as 18 pieces. The prepared soil, sludge, and compost were each dried. Soil, sludge, and compost were then sieved with a $2 \mathrm{~mm}$ sieve. Each uniform soil, sludge, and compost was sampled for testing to determine the initial $\mathrm{Zn}, \mathrm{NPK}$, and water content in the material. The test was conducted to determine the required compost that is suitable for the needs of $\mathrm{N}$ and water. The soil and sludge that had been tested were mixed according to the treatment, soil without sludge and soil with $40 \%$ sludge. Then, it was homogenized by stirring and put into the pot that had been prepared as many as 18 pieces. The filled pots of each planting medium were weighed and calculated to know the field capacity.

The availability of water in the soil was an important factor for the growth of the sunflower, and a good moisture content (\% weight) of the sunflower clay texture was $62.18 \%$. The capacity arrangement was done by taking samples of soil that are placed in a container that had two holes at the bottom and top, and then, the bottom hole was closed using a gauze that had been weighed previously. Furthermore, the initial soil was weighed to be 10 grams. Once weighed, the soil and the container were dipped into the water until filled sufficiently, and the top of the container hole was covered with plastic and then ignored until the soil is saturated in absorbing water. Then, the saturated soil was drained until no water is dripped and weighed as wet weight. Then, the soil was dried using an oven at $105^{\circ} \mathrm{C}$ for 24 hours and found dry soil. Herein, field capacity (FC) $100 \%$ can be obtained by the following calculation:

$$
\mathrm{FC}=\frac{\text { (wet weight of soil }- \text { dry weight of soil) }}{\text { dry weight of soil }} \times 100 \text {. }
$$

Addition of water was done to meet the needs of plants ranging from 60 to $100 \%$ of field capacity. In conjunction with water field capacity, $160 \mathrm{mg}$ of $\mathrm{ZnCl}_{2}$ was added in $1 \mathrm{~kg}$ sludge by dissolving into water, and it was poured into sludge evenly with 3 times rinse and was left for 24 hours. Then, $2 \mathrm{Na}$-EDTA chelating agent of $0 \mathrm{mg} / \mathrm{kg}, 876.72 \mathrm{mg} / \mathrm{kg}$, and $1461.2 \mathrm{mg} / \mathrm{kg}$ was added to soil with three replications each. Before planting was done, the medium was added with compost as much as 3.3 gram, and then it was stirred until blended.

2.4.2. Planting of Sunflower Seeds. Transplantation is the transfer of plants from a shedding medium to planting medium. In this study, seeds of sunflower plants were first taken on the tray of seedlings, and then, they entered the planting medium with each treatment. Planting on the tray is done for 1 week of plant age with an average height of $8 \mathrm{~cm}-10 \mathrm{~cm}$ and leaf number of 2-4 pieces.

2.4.3. Monitoring. Maintenance of sunflower plants (Helianthus annuus L.) at the time of growth was done by watering the plants and also the selection of plants at the age of 2 weeks. The sunflower plants were watered with tap water with the provision of the water holding capacity of $60-100 \%$, and rewatering was done if the water content was less than the water holding capacity. After 2 weeks of planting in pots, 2 sunflower plants would be selected for which the average growth had the 
same high characteristics and the same number of leaves for analysis. Provision of insecticides for 1-month-old plants is to prevent the arrival of pests.

Observations of sunflower plants include measurements of room temperature and soil, soil $\mathrm{pH}$, plant height, and leaf count calculations. Temperature and $\mathrm{pH}$ measurements were performed every day morning and evening using a soil tester. The measurement of plant height and leaf count calculation is done once every 1 week.

2.4.4. Harvesting. Harvesting was done at the 8 th week after planting. The samples were taken from 18 pots. Sunflower was taken the root, stems, and leaves to know the absorption of the heavy metal zinc ( $\mathrm{Zn})$ in sunflower plants. The stage of sunflower harvesting includes (1) separation of the stem from its roots by cutting the stem part above the soil surface, (2) separation of leaves from the stem, and (3) separation of roots with soil; after being separated, the roots are washed with water and then dried. The root of the leaf stalk is inserted into the sample place. The soil sample to be taken on one pot that was homogenized first was dried on the tray. The drying of the soil was carried out for 1 day. After drying, the soil was pounded using mortar. The soil that had been subtly ground was then put in a plastic clip of 300 grams. Then, samples of sunflower and soil had been taken to the laboratory for testing $\mathrm{Zn}$ concentration.

2.4.5. Laboratory Test. Analysis of soil samples was performed twice, that is, on the initial soil and soil after treatment. Initial soil samples were taken for testing the concentrations of $\mathrm{Zn}$ and NPK metals contained in the initial soil. Soil after treatment only tested its $\mathrm{Zn}$ concentration. Testing of $\mathrm{Zn}$ metal concentration on soil was done at Chemical Laboratory, and NPK testing was conducted at Soil Chemistry Laboratory in University of Brawijaya.

Testing of $\mathrm{Zn}$ concentration on soil begins by weighing 1 gram of the soil sample, it is then put into the reaction tube, and $10 \mathrm{~mL}$ of $\mathrm{HNO}_{3}$ is added. After it was heated for \pm 15 minutes with a temperature of $350^{\circ} \mathrm{C}$, it was cooled. The quads were added to $25 \mathrm{~mL}$ and filtered with a $0.42 \mu$ pore membrane filter. The tool used to read the concentration of the $\mathrm{Zn}$ metal on the soil was the Atomic Absorption Spectrophotometry (AAS) Shimadzu AA-6200 type.

Total $N$ tests on the initial soil were carried out by the Kjeldahl method. The test procedure was to weigh $0.5 \mathrm{~mm}$ of $0.5 \mathrm{~mm}$ soil samples and then add 1 gram of selenium mixture and $5 \mathrm{~mL}$ of concentrated $\mathrm{H}_{2} \mathrm{SO}_{4}$, after which the mixed material was heated to $300^{\circ} \mathrm{C}$. When the heating results were complete, the mixture was diluted with $50 \mathrm{~mL}$ pure $\mathrm{H}_{2} \mathrm{O}$. The heating product was diluted to $\pm 100 \mathrm{~mL}$ and added with $40 \%$ $\mathrm{NaOH} .20 \mathrm{~mL}$ boric acid was added to the mixture; boric acid serves as an indicator of discoloration. The last step was to do the titration until the $\mathrm{H}_{2} \mathrm{SO}_{4}$ solution was at $0.1 \mathrm{~N}$ point.

$\mathrm{P}$ test was done on soil using the spectrophotometric method, Bray-1 extract, and Bray-2 extract. The test procedure was to take 1.5 grams of soil samples that pass through a $2 \mathrm{~mm}$ sieve, add Bray and Kurtz I extract as much as $15 \mathrm{~mL}$, shake it for $5 \mathrm{~min}$, and filter with a membrane pore size $0.42 \mu$.
TABLe 1: Zn test results on planting media.

\begin{tabular}{lccc}
\hline \multirow{2}{*}{ Number } & \multirow{2}{*}{ Media } & \multicolumn{2}{c}{ Analysis results } \\
& & Zn levels & Units \\
\hline 1 & Soil & $186.77 \pm 0.12$ & $\mathrm{mg} / \mathrm{kg}$ \\
2 & Sludge & $0.13 \pm 0.00$ & $\%$ \\
3 & Compost & $0.02 \pm 0.00$ & $\%$ \\
4 & Faucet water & Not detected & $\mathrm{mg} / \mathrm{L}$ \\
\hline
\end{tabular}

Then, add aquades up to $25 \mathrm{~mL}$ and phosphate reagent. Then, the result of the solution can be read on Spectronic 21 .

The testing procedure of $K$ concentration on the soil sample that was weighing 1 gram was added with $10 \mathrm{~mL}$ of the $\mathrm{NH}_{4} \mathrm{OAc}$ solution of $\mathrm{pH} 7$ and homogenized. Then, it was filtered with a filter paper membrane with a pore size of $0.42 \mu$, and the filtrate accommodated in the container. Then, $10 \mathrm{~mL}$ of $\mathrm{NH}_{4} \mathrm{OAc}$ solution was added again, homogenized again, and filtered through a $0.42 \mu$ pore membrane filter. Then, $10 \mathrm{~mL}$ of the $\mathrm{NH}_{4} \mathrm{OAc}$ solution was added again, the sample was centrifuged for 10 minutes, and the filtrate was collected back into the container. Calculations are performed using standard curves (standard curve regression).

2.4.6. Data Analysis. This study used the Completely Randomized Design (CRD) method on $2 \times 3$ factorial with three repetitions. The first factor is the process of planting media, that are planting media without polluted sludge and planting media contaminated with $40 \%$ sludge. The second factor is the addition of EDTA concentration, that is, $0 \mathrm{mg} / \mathrm{kg}, 876.72 \mathrm{mg} / \mathrm{kg}$, and $1461.2 \mathrm{mg} / \mathrm{kg}$ of soil. Each treatment consists of 3 repetitions.

\section{Results and Discussion}

3.1. Characteristics of Planting Media and Materials Prior to Treatment. Physical characteristics of the soil before the research were solid form, black, and odorless. The physical characteristics of sludge were solid, brown, and smelly. The physical characteristics of compost were solid, black, and odorless. Each planting medium was tested early to determine the $\mathrm{Zn}$ levels used before. The testing results of the initial $\mathrm{Zn}$ content of planting medium can be seen in Table 1.

\subsection{Environmental Condition during Research. Environmental} conditions during the study include room temperature and soil temperature. The room was measured, and soil temperature was noted to know the condition of temperature in place of research (greenhouse) and also on soil planting media. Room temperature measurements were performed at the minimum temperature (morning) from 07:00 to 08:00 and at the maximum temperature (noon) from 12:00 to 13:00 daily for 42 days. The average graph of room temperature of the study site and the average soil temperature can be seen in Figure 1.

Figure 1(a) shows the temperature of the greenhouse room during sunflower plant growth with a mean value of $37^{\circ} \mathrm{C}$ and an average temperature of at least $21^{\circ} \mathrm{C}$. This is in accordance with the opinion of Khalifa et al.[23], where the maximum growth of indoor sunflower germination occurs at a temperature of $20.4^{\circ} \mathrm{C}$ to $37.6^{\circ} \mathrm{C}$. 


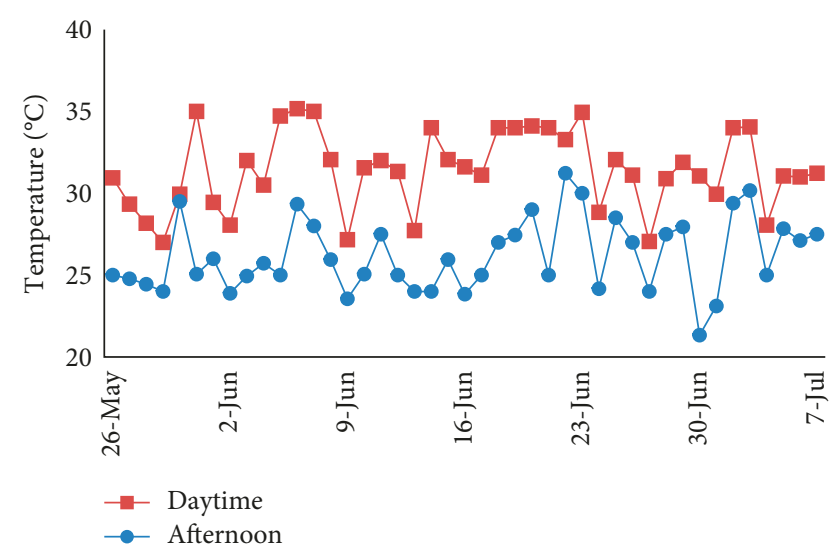

(a)

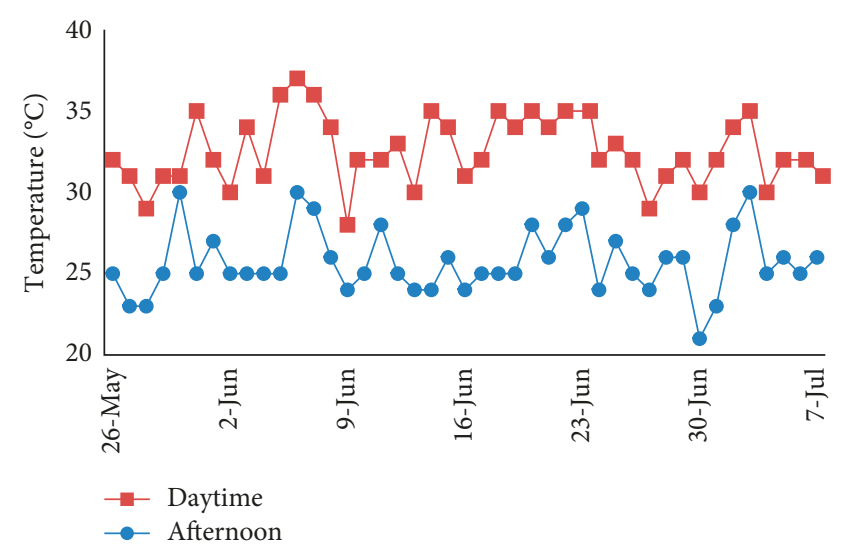

(b)

FIGURE 1: Graph of temperature: (a) room temperature and (b) soil temperature.

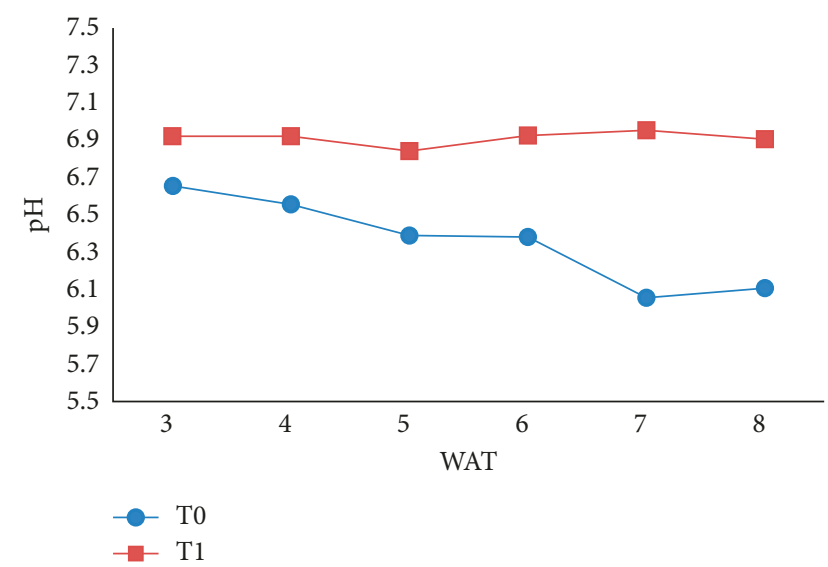

Figure 2: Average graph of soil $\mathrm{pH}$.

Figure 1(b) shows the soil temperature during the growth of sunflower plants. It also shows that it still meets the tolerable temperature tolerance limits with a mean value of a maximum temperature of $35.17^{\circ} \mathrm{C}$ and a minimum average temperature of $21.33^{\circ} \mathrm{C}$. The growth of sprouts and sunflower seeds (Helianthus annuus L.) is good at temperatures of $10^{\circ} \mathrm{C}$ and $35.5^{\circ} \mathrm{C}$.

Figure 2 shows that the average soil $\mathrm{pH}$ per week in the T1 treatment ( $60 \%$ soil $+40 \%$ sludge) is higher than in the T0 treatment (100\% soil). The $\mathrm{Tl}$ treatment had an average soil $\mathrm{pH}$ ranging from 6.8 to 7.0 , whereas the T0 treatment had an average soil $\mathrm{pH}$ ranging from 6.0 to 6.8. Sunflower plants grow well at a pH ranging from 5.7 to 8.1 . The soil $\mathrm{pH}$ reaction outside the 6-7 range may result in a decrease in the availability of certain nutrients and sometimes lead to the availability of other nutrients.

3.3. Plant Height. The height of sunflower plants at the beginning of planting had the same average height of $8 \mathrm{~cm}$. At the 1st WAT (weeks after transplant), the high growth of sunflower plants tended to have no significant difference. The height of the sunflower plants in the T0K0 and T1K0 treatments (without EDTA addition) showed significantly different growth at 2 weeks after transplantation. The 3rd week after transplantation of each treatment tends to show the difference of plant growth that is real but still related. Plant height growth at T0K0 was significantly

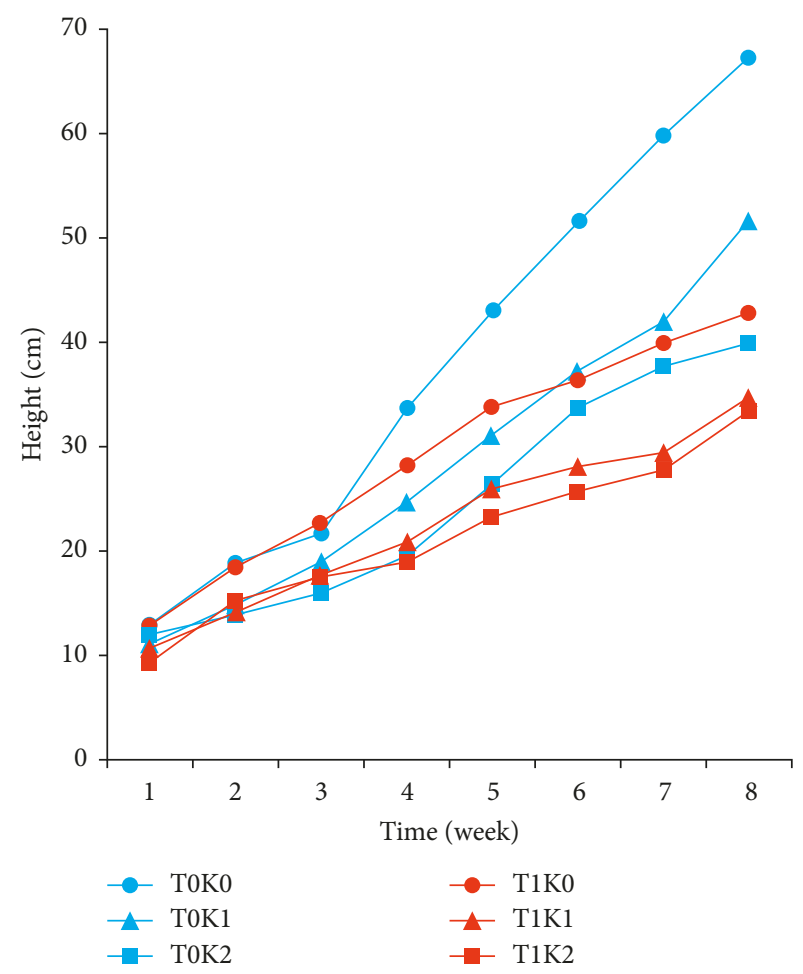

FIGURE 3: Average growth of plants.

higher than that in other treatments at the 4th-8th WAT. Treatment of T0K1, T0K2, T1K1, and T1K2 with EDTA addition had significantly different plant height growth that is still related. Treatment without EDTA addition tended to have higher high growth compared with treatment with EDTA addition.

T0 treatment had higher plant growth than T1 treatment, and this was because the addition of sludge on planting medium causes plant growth to be inhibited. Sludge had a hard characteristic that makes it difficult for rooting zones to grow [6]. The increasing concentration of EDTA also causes plant growth to be inhibited. The addition of EDTA to the growing medium causes $\mathrm{Zn}$ available in the soil which is then absorbed by the increasing sunflower plants. The average graph of high growth of sunflower can be seen in Figure 3. 


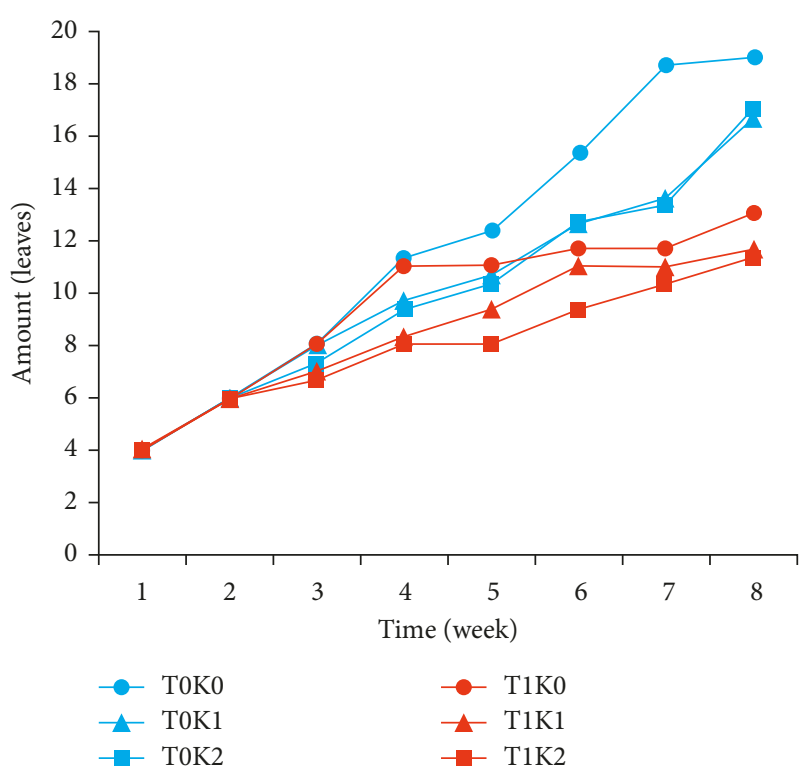

FIGURE 4: Graph of the average growth of leaves amount.

Growth of sunflower plants had increased weekly (1st-8th WAT). Differences in the plant height began to be seen in the 4th WAT. At the 4th-8th WAT, the T0K0 treatment showed a significant high difference compared with other treatments.

The T0K0 treatment had the best high growth compared to other treatments. T0 treatment (100\% soil) with the addition of different EDTA concentrations had a significant high difference at the 8 th WAT. Treatment of T1 (60\% soil $+40 \%$ sludge) with the addition of different EDTA concentrations tended not to have a significant high difference at the 8th WAT. Maximum height growth of sunflower plants is found in the T0K0 treatment, and the minimal growth of sunflower plants is found in the $\mathrm{T} 1 \mathrm{~K} 2$ treatment. The addition of sludge to planting media not only damages the root zone due to its hard texture but also inhibits the growth of sunflower plants due to its high $\mathrm{Zn}$ content. The increasing concentration of EDTA also causes the heavy metal content of $\mathrm{Zn}$ in soil to increase. According to Novitasari et al. [24], based on observation data on the effect of metal $\mathrm{Zn}$ concentration on the plant height taken for 8 weeks, the higher $\mathrm{Zn}$ concentration would reduce the height of the sunflower plants.

T0 treatment had an average leaf number greater than T1 treatment. The average grain growth of leaf number indicates that the addition of sludge with higher $\mathrm{Zn}$ concentration causes stunted leaf growth. The graph of average growth of leaf amount can be seen in Figure 4.

The excess $\mathrm{Zn}$ metal in Jatropha plants causes yellowing of leaves. When the plants are exposed to excess metal $\mathrm{Zn}$ for longer time, the yellowish leaves turn brown, showing the symptoms of chlorosis and necrosis, and become small. Based on the research Novitasari [24], the higher $\mathrm{Zn}$ content in plants will cause more severe leaf damage such as chlorosis, necrosis, and abnormal leaf growth. Leaf damage can also be caused by environmental conditions such as animal/pest disturbance at the time of the research.
TABLE 2: Wet weight of plants.

\begin{tabular}{lccccc}
\hline Treatment & Root & Trunk & $\begin{array}{c}\text { Flower } \\
\text { g/plant }\end{array}$ & Leaf & Total \\
\hline T0K0 & $4.88^{\mathrm{b}}$ & $13.93^{\mathrm{c}}$ & $17.76^{\mathrm{d}}$ & $6.60^{\mathrm{c}}$ & $31.33^{\mathrm{c}}$ \\
T0K1 & $1.94^{\mathrm{a}}$ & $8.01^{\mathrm{b}}$ & $11.76^{\mathrm{c}}$ & $3.91^{\mathrm{b}}$ & $17.79^{\mathrm{b}}$ \\
T0K2 & $2.00^{\mathrm{a}}$ & $5.46^{\mathrm{ab}}$ & $11.75^{\mathrm{c}}$ & $3.36^{\mathrm{b}}$ & $14.74^{\mathrm{b}}$ \\
T1K0 & $0.81^{\mathrm{a}}$ & $3.27^{\mathrm{a}}$ & $5.55^{\mathrm{b}}$ & $1.11^{\mathrm{ab}}$ & $7.05^{\mathrm{ab}}$ \\
T1K1 & $0.56^{\mathrm{a}}$ & $1.80^{\mathrm{a}}$ & $2.77^{\mathrm{a}}$ & $0.57^{\mathrm{a}}$ & $3.87^{\mathrm{a}}$ \\
T1K2 & $0.78^{\mathrm{a}}$ & $2.12^{\mathrm{a}}$ & $3.53^{\mathrm{ab}}$ & $0.71^{\mathrm{a}}$ & $4.80^{\mathrm{a}}$ \\
BNT 5\% & 1.82 & 4.68 & 2.76 & 2.28 & 9.46 \\
\hline
\end{tabular}

The numbers followed by different letters in the same column give different effect to the height of sunflower plants (Helianthus annuus L.) at 5\% LSD (least significant difference) test level.

3.4. Wet Weight and Dry Weight Plants. Wet weight and dry weight were measured at the 9 th week to determine the mass growth of sunflower plants. Measurement of wet weight and dry weight is divided into 4 parts: flowers, leaf, trunk, and root. Data on the measurement of wet weight and dry weight of sunflower plants at the 8th WAT can be seen in Tables 2 and 3 , respectively.

The wet weight of roots, leaves, flowers, and stems was significantly different at 5\% significance level. The T0K0 treatment had a significantly higher wet weight value compared to the other treatments at the root.

In the treated roots, T0K0 and T0K1 had significantly higher wet weight values compared to other treatments. T0 treatment had shown significant differences in wet weight on the flower portion compared with T1 treatment.

Statistical calculations of dry weight show that the root, leaf, flower, and stem had different effects on the $5 \%$ confidence level. The T0K0 treatment had a significantly higher dry weight compared with the other treatments at the root. The stem section shows that T0 treatment had a significantly higher dry weight than $\mathrm{T} 1$ treatment. The interest rate tends to show no significant difference in dry weight in each treatment. The T0 treatment had a significantly higher dry weight than the $\mathrm{T} 1$ treatment on the leaf. T0 treatment tended to have higher dry weight than T1 treatment for the total dry weight of sunflower plants.

In both wet weight and dry weight, T0 treatment (100\% soil) has an average weight of plants higher than T1 treatment $(60 \%$ soil $+40 \%$ sludge $)$. Sunflower plants grown on planting media with a combination of sludge growth is inhibited.

This is because the planting medium with a combination of sludge contains higher levels of $\mathrm{Zn}$ compared with soil crop media sludge characteristics that tend to be hard and dry, which also make the development of the root zone of sunflower plants to be disturbed. The result is that sunflower plants grown on planting medium with a combination of sludge has a smaller growth rate compared to that grown on soil media. In accordance with the opinion of Mcbride et al. [8], the addition of sludge to the soil resulted in increased permeability on the soil. Permeability affects root penetration, water penetration rate, water absorption rate, internal drainage, and nutrient leaching [3]. According to Norvell [5], the results observed from the growth of sengon and mangium 
TABle 3: Dry weight of plants.

\begin{tabular}{lccccc}
\hline Treatment & Root & Trunk & $\begin{array}{c}\text { Flower } \\
\text { g/plant }\end{array}$ & Leaf & Total \\
\hline T0K0 & $0.76^{\mathrm{b}}$ & $2.07^{\mathrm{c}}$ & $0.98^{\mathrm{bc}}$ & $1.25^{\mathrm{c}}$ & $5.06^{\mathrm{c}}$ \\
T0K1 & $0.21^{\mathrm{a}}$ & $1.08^{\mathrm{bc}}$ & $0.62^{\mathrm{b}}$ & $0.70^{\mathrm{b}}$ & $2.62^{\mathrm{b}}$ \\
T0K2 & $0.18^{\mathrm{a}}$ & $0.91^{\mathrm{b}}$ & $0.64^{\mathrm{b}}$ & $0.67^{\mathrm{b}}$ & $2.42^{\mathrm{b}}$ \\
T1K0 & $0.12^{\mathrm{a}}$ & $0.62^{\mathrm{ab}}$ & $0.34^{\mathrm{ab}}$ & $0.30^{\mathrm{a}}$ & $1.40^{\mathrm{ab}}$ \\
T1K1 & $0.07^{\mathrm{a}}$ & $0.29^{\mathrm{a}}$ & $0.17^{\mathrm{a}}$ & $0.16^{\mathrm{a}}$ & $0.69^{\mathrm{a}}$ \\
T1K2 & $0.12^{\mathrm{a}}$ & $0.40^{\mathrm{ab}}$ & $0.23^{\mathrm{ab}}$ & $0.21^{\mathrm{a}}$ & $0.96^{\mathrm{a}}$ \\
BNT 5\% & 0.40 & 0.59 & 0.44 & 0.59 & 1.34 \\
\hline
\end{tabular}

The numbers followed by different letters in the same column give different effect to the height of sunflower plants (Helianthus annuus L.) at 5\% LSD (least significant difference) test level.

seedlings in solid soil suggest that the depth of root penetration and high growth decreases with increasing soil density.

The results of wet weight and dry weight tests also show that the increasing concentration of EDTA in planting medium inhibits higher growth of sunflower plants. The increasing concentration of EDTA in the soil caused the high concentration of the heavy metal $\mathrm{Zn}$ on the ground, which was then absorbed by the tissue of sunflower plants (Helianthus annuus L.)

3.5. Analysis of Zn Concentration in Soil and Plants. This study analyzes the concentration of the heavy metal $\mathrm{Zn}$ found in soil and sunflower plants to determine the concentration of $\mathrm{Zn}$ in soil and plants. The plant part consists of roots, leaves, flowers, and stems. The effect of sludge and EDTA addition treatment on the mean of total $\mathrm{Zn}$ concentration on the soil and sunflower plants can be seen in Table 4 .

The average concentration of $\mathrm{Zn}$ on soil and plants has a significant difference in the $5 \%$ confidence level. The accumulation of the $\mathrm{Zn}$ metal on soil showed significant differences between $\mathrm{T} 0$ and $\mathrm{T} 1$ treatments.

The value of $\mathrm{Zn}$ metal content is highest in $\mathrm{T} 1 \mathrm{~K} 2$ treatment and lowest in T0K2 treatment. The result of the $\mathrm{Zn}$ test on the plant showed significant differences, and the value of the $\mathrm{Zn}$ metal content is highest in T0K2 treatment and lowest in T1K0 treatment.

The uptake value obtained from the dry weight of the plant divided by the number of plants per pot was then multiplied by the concentration of $\mathrm{Zn}$. T0 treatment $(100 \%$ soil) had a higher uptake value compared with T1 treatment $(60 \%$ soil $+40 \%$ sludge $)$.

T1 treatment had a higher $\mathrm{Zn}$ concentration on soil compared with T0 treatment. This was because sludge had a higher initial $\mathrm{Zn}$ content than the soil. The addition of EDTA had an effect on the $\mathrm{Zn}$ concentration in plants. The more the EDTA addition, the higher the Zn concentration in the plant. Uptake values tend not to have significant differences, and the highest uptake value in the T0K0 treatment was with a total absorption of $179.00 \mathrm{mg} /$ plant.

Zn concentration which was absorbed by sunflower plants (Helianthus annuus L.) was $\mathrm{Zn}$ available in soil. The addition of chelating compounds in the soil may not only increase the total concentration of dissolved metals but also alter the absorption mechanism. Depending on the type of the metal,
TABLE 4: Level of $\mathrm{Zn}$ metal on soil and sunflower plants.

\begin{tabular}{|c|c|c|c|}
\hline \multirow[b]{2}{*}{ Treatment } & \multicolumn{2}{|c|}{ Concentration of $\mathrm{Zn}$} & \multirow[b]{2}{*}{$\begin{array}{l}\text { Uptake of } \mathrm{Zn} \\
\text { (mg/plant) }\end{array}$} \\
\hline & $\begin{array}{c}\text { Soil } \\
(\mathrm{mg} / \mathrm{kg})\end{array}$ & $\begin{array}{c}\text { Plant } \\
(\mathrm{mg} / \mathrm{kg})\end{array}$ & \\
\hline T0K0 & $163.62^{\mathrm{a}}$ & $101.74^{\mathrm{b}}$ & $179.00^{c}$ \\
\hline T0K1 & $159.8^{\mathrm{a}}$ & $136.91^{\mathrm{bc}}$ & $122.33^{\mathrm{b}}$ \\
\hline T0K2 & $155.57^{\mathrm{a}}$ & $160.17^{c}$ & $139.67^{\mathrm{bc}}$ \\
\hline $\mathrm{T} 1 \mathrm{~K} 0$ & $289.31^{\mathrm{c}}$ & $61.22^{\mathrm{a}}$ & $31.33^{\mathrm{a}}$ \\
\hline T1K1 & $251.07^{\mathrm{b}}$ & $151.71^{\mathrm{c}}$ & $38.67^{\mathrm{a}}$ \\
\hline $\mathrm{T} 1 \mathrm{~K} 2$ & $306.31^{\mathrm{c}}$ & $137.35^{\mathrm{bc}}$ & $53.33^{\mathrm{ab}}$ \\
\hline BNT 5\% & 21.37 & 37.79 & 71.23 \\
\hline
\end{tabular}

The numbers followed by different letters in the same column give different effect to the height of sunflower plants (Helianthus annuus L.) at 5\% LSD (least significant difference) test level.

TABLE 5: Efficiency of $\mathrm{Zn}$ weight loss by sunflower plants.

\begin{tabular}{lc}
\hline Treatment & Percentage removal \\
\hline T0K0 & 96 \\
T0K1 & 65 \\
T0K2 & 75 \\
T1K0 & 4 \\
T1K1 & 6 \\
T1K2 & 8 \\
\hline
\end{tabular}

the type of the plant, and the concentration of the engaging compound, absorption is significantly improved [12].

The removal percentage was calculated to determine the absorption ability of sunflower plants in reducing the heavy metal $\mathrm{Zn}$. The efficiency of heavy metal removal by plants is determined by

$$
\text { efficiency }=\frac{\mathrm{Zn} \text { uptake }}{\text { initial } \mathrm{Zn}}
$$

Table 5 shows that T0 treatment with an initial $\mathrm{Zn}$ content of soil of $186.77 \mathrm{mg} / \mathrm{kg}$ can reduce $\mathrm{Zn}$ weight by $96 \%$ (T0K0), $65 \%$ (T0K1), and 75\% (T0K2). T1 treatment with an initial Zn content in soil of $696,062 \mathrm{mg} / \mathrm{kg}$ was capable of reducing $\mathrm{Zn}$ weight by $4 \%$ (T1K0), 6\% (T1K1), and 8\% (T1K2).

T0 treatment (100\% soil) showed better removal efficiency compared to $\mathrm{T} 1$ ( $60 \%$ soil $+40 \%$ sludge $)$. This was because $\mathrm{T} 1$ treatment had a very high initial $\mathrm{Zn}$ content compared with T0 treatment. The very high content of the heavy metal $\mathrm{Zn}$ on the soil causes toxic effects on plants that can decrease the ability of plant absorption in the phytoremediation process. According to Namgay et al. [12], plant growth requires only a small amount of $\mathrm{Zn}$ content compared to macronutrients. $\mathrm{Zn}$ in large quantities would cause damage to plant tissue.

The addition of EDTA causes the growth of sunflower plants to be inhibited and can decrease the absorption efficiency of the heavy metal $\mathrm{Zn}$ by sunflower plants. The addition of EDTA to the T1 treatment tended to have no significant effect. This is because the initial $\mathrm{Zn}$ content of the T1 treatment is too high, causing the sunflower plants to have heavy metal $\mathrm{Zn}$ toxicity and damage to the plant tissue. 


\section{Conclusion}

(1) The sunflower planted in the T1 treatment (60\% soil $+40 \%$ sludge) has lower mean height and weight than the sunflower planted in the T0 treatment (100\% soil). The addition of sludge as much as $1.5 \mathrm{~kg}$ on planting medium resulted in the inhibited growth of sunflower plants (Helianthus annus L.).

(2) The most efficient absorption of the heavy metal $\mathrm{Zn}$ was on the T0K0 treatment $(100 \%$ soil and $0 \mathrm{mg} / \mathrm{kg}$ EDTA) with the total of $\mathrm{Zn}$ concentration of 101.74 $\mathrm{mg} / \mathrm{kg}$ in plants. The T0K0 treatment is capable of reducing $\mathrm{Zn}$ weight by up to $96 \%$ of total $\mathrm{Zn}$ available on the soil.

(3) The addition of EDTA chelating agents affects the concentration of the heavy metal $\mathrm{Zn}$ on the sunflower plant tissue. The greater the addition of EDTA, the greater the concentration of heavy metals in the sunflower plant tissue. The addition of EDTA to $100 \%$ of the soil causes the decrease in the absorption efficiency of the heavy metal Zn by sunflower plants. The addition of EDTA to $40 \%$ sludge did not affect the absorption of the heavy metal Zn by sunflower plants.

\section{Data Availability}

The data used to support the findings of this study are available from the corresponding author upon request.

\section{Conflicts of Interest}

The authors declare that they have no conflicts of interest.

\section{Acknowledgments}

The authors thank the management of Laboratory of Environmental and Natural Resources Engineering, Faculty of Agricultural Technology, University of Brawijaya.

\section{References}

[1] A. Karaca, "Effect of organic wastes on the extractability of cadmium, copper, nickel, and zinc in soil," Geoderma, vol. 122, no. 2-4, pp. 297-303, 2004.

[2] B. Nowack, R. Schulin, and B. H. Robinson, "Critical assessment of chelant-enhanced metal phytoextraction," Environmental Science \& Technology, vol. 40, no. 17, pp. 5225-5232, 2006.

[3] M. Friedlová, "The influence of heavy metals on soil biological and chemical properties," Soil and Water Research, vol. 5, no. 1, pp. 21-27, 2010.

[4] J. Wyszkowska, J. Kucharski, M. Kucharski, and A. Borowik, "Effect of cadmium, copper and zinc on plants, soil microorganisms and soil enzymes," Journal of Elementology, vol. 18, no. 4, pp. 769-796, 2012.

[5] W. A. Norvell, "Comparison of chelating agents as extractants for metals in diverse soil materials," Soil Science Society of America Journal, vol. 48, no. 6, pp. 1285-1292, 1984.

[6] A. Ghani, "Toxic effects of heavy metals on plant growth and metal accumulation in maize (Zea mays L.)," Iranian Journal of Toxicology, vol. 3, no. 3, pp. 325-334, 2010.
[7] A. G. Khan, "Role of soil microbes in the rhizospheres of plants growing on trace metal contaminated soils in phytoremediation," Journal of Trace Elements in Medicine and Biology, vol. 18, no. 4, pp. 355-364, 2005.

[8] M. B. Mcbride and C. E. Martínez, "Copper phytotoxicity in a contaminated soil: remediation tests with adsorptive materials," Environmental Science and Technology, vol. 34, no. 20, pp. 4386-4391, 2000.

[9] G. U. Chibuike, "Use of mycorrhiza in soil remediation: a review," Scientific Research and Essays, vol. 8, no. 35, pp. 1679-1687, 2013.

[10] C. Garbisu and I. Alkorta, "Basic concepts on heavy metal soil bioremediation," European Journal of Mineral Processing and Environmental Protection, vol. 3, no. 1, pp. 58-66, 2003.

[11] E. Lombi, F. J. Zhao, S. J. Dunham, and S. P. McGrath, "Phytoremediation of heavy metal-contaminated soils: natural hyperaccumulation versus chemically enhanced phytoextraction," Journal of Environmental Quality, vol. 30, no. 6, pp. 1919-1926, 2001.

[12] T. Namgay, B. Singh, and B. P. Singh, "Influence of biochar application to soil on the availability of $\mathrm{As}, \mathrm{Cd}, \mathrm{Cu}, \mathrm{Pb}$, and $\mathrm{Zn}$ to maize (Zea mays L.)," Soil Research, vol. 48, no. 6-7, pp. 638-647, 2010.

[13] G. Rout and P. Das, "Effect of metal toxicity on plant growth and metabolism: I. Zinc," Agronome, vol. 23, no. 1, pp. 3-11, 2003.

[14] L. Van Ginneken, E. Meers, R. Guisson et al., "Phytoremediation for heavy metal-contaminated soils combined with bioenergy production," Journal of Environmental Engineering and Landscape Management, vol. 15, no. 4, pp. 227-236, 2007.

[15] R. D. Reeves and A. J. M. Baker, "Metal-accumulating plants," in Phytoremediation of Toxic Metals: Using Plants to Clean Up the Environment, I. Raskin and B. D. Ensley, Eds., pp. 193229, Wiley, New York, NY, USA, 2000.

[16] C. D. Jadia and M. H. Fulekar, "Phytoremediation of heavy metals: recent techniques," African Journal of Biotechnology, vol. 8, no. 6, pp. 921-928, 2009.

[17] D. C. Adriano, W. W. Wenzel, J. Vangronsveld, and N. S. Bolan, "Role of assisted natural remediation in environmental cleanup," Geoderma, vol. 122, no. 2-4, pp. 121-142, 2004.

[18] R. Ajaz Haja Mohideena, V. Thirumalai Arasuc, K. R. Narayananb, and M. I. Zahir Hussaind, "Bioremediation of heavy metal contaminated soil by the exigobacterium and accumulation of $\mathrm{Cd}, \mathrm{Ni}, \mathrm{Zn}$ and $\mathrm{Cu}$ from soil environment," International Journal of Biological Technology, vol. 1, no. 2, pp. 94-101, 2010.

[19] S. Ike Rismawati, Phytoremediation of Zn Heavy Zn Land Using Jatropha curcas, Sepuluh Nopember Institute of Technology, Surabaya, Indonesia, 2012.

[20] J. L. Schanoor and S. C. dan McCutcheon, Phytoremediation Transformation and Control of Contaminant, Wiley-Interscience Inc, Hoboken, NJ, USA, 2017, https://books.google.co.id.

[21] A. P. G. C. Marques, R. S. Oliveira, A. O. S. S. Rangel, and P. M. L. Castro, "Application of manure and compost to contaminated soils and its effect on zinc accumulation by Solanum nigrum inoculated with arbuscular mycorrhizal fungi," Environmental Pollution, vol. 151, no. 3, pp. 608-620, 2008.

[22] F. Navari-Izzo and M. F. Quartacci, "Phytoremediation of metals," Minerva Biotecnologica, vol. 13, no. 2, pp. 73-83, 2001.

[23] F. M. Khalifa, A. A. Schneiter, and E. I. Eltayeb, "Temperaturegermination responses of sunflowers (Helianthus annuus L.) genotypes," HELIA, vol. 23, no. 33, pp. 97-104, 2000. 
[24] B. P. Novitasari, The Influence of Zinc Concentration ( $\mathrm{Zn}$ ) in Soil is Polluted to the Sunflower Absorption (Helianthus annuus L) in the Vegetative Phase, Universitas Brawijaya, Department of Agricultural Engineering, Malang, Indonesia, 2017.

[25] D. E. Salt, R. D. Smith, and I. Raskin, "Phytoremediation," Annual Review of Plant Biology, vol. 49, no. 1, pp. 643-668, 1998. 

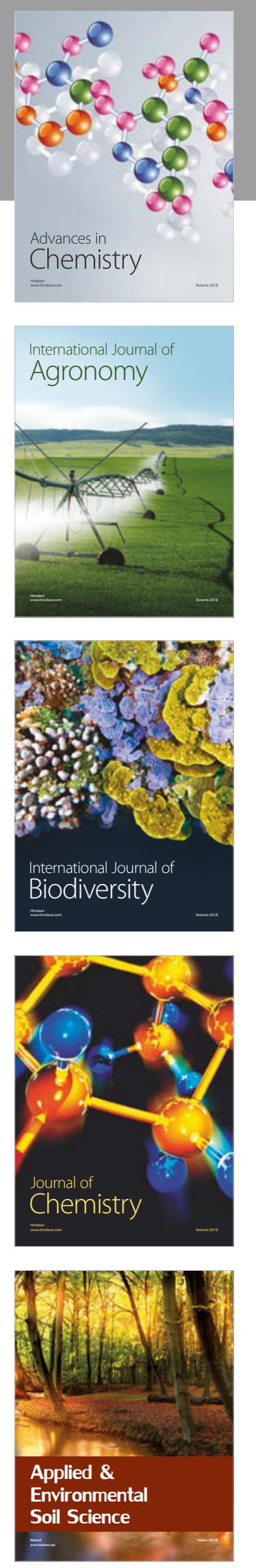

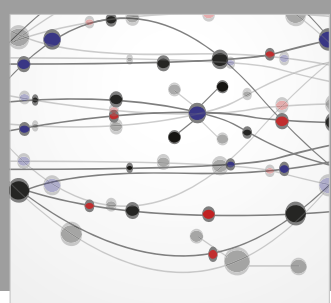

The Scientific World Journal

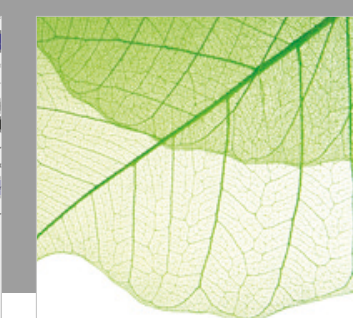

Journal of Botany

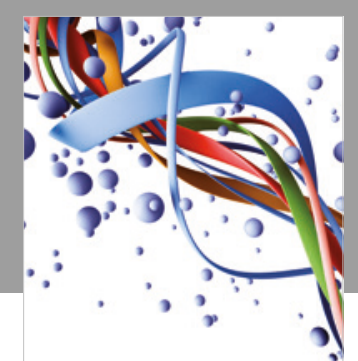

Scientifica

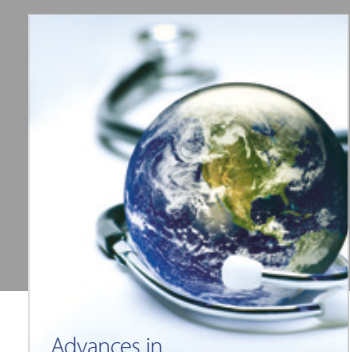

Public Health

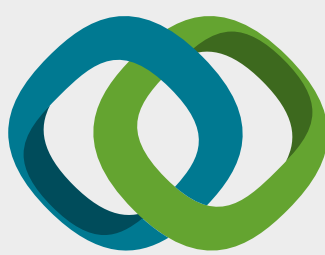

Hindawi

Submit your manuscripts at

www.hindawi.com
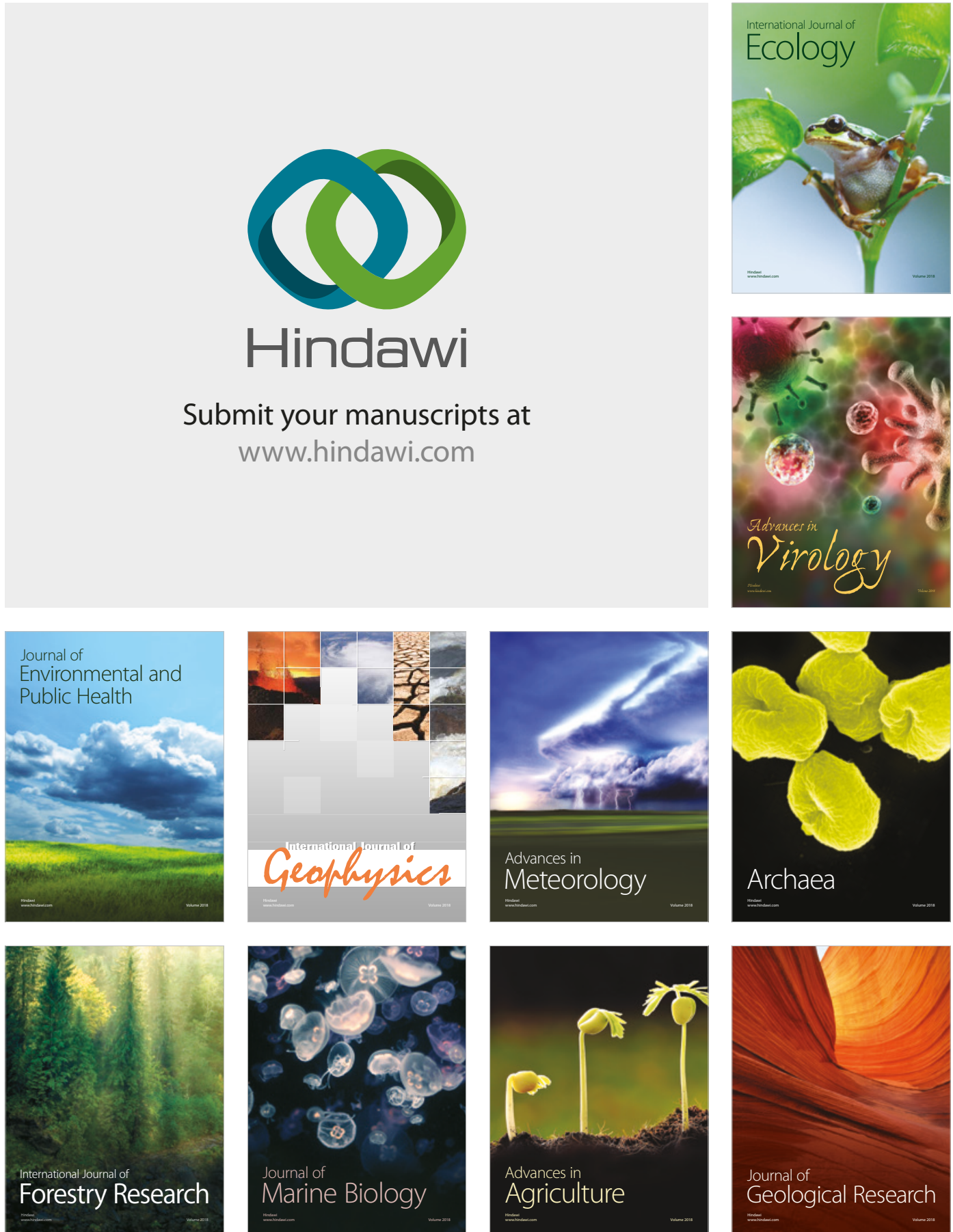

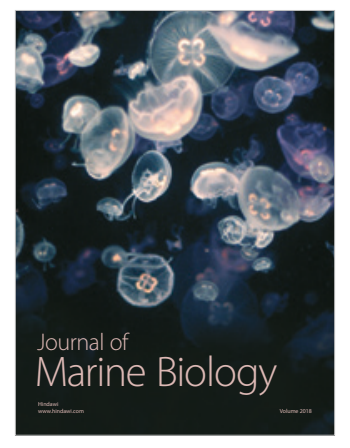

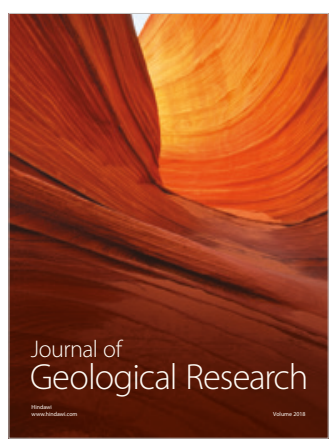

